УДК 378.1:330.180

DOI: $10.15673 /$ fie.v12i3.1816

Постоян Т.Г.

кандидат педагогчних наук, доцент

кафедра освітнього менеджменту та публічного управління

E-mail: postoyantatyana@gmail.com

ORCID ID: 0000-0002-5549-8243

Черненко I.B.

магистрант

кафедра освітнього менеджменту та публічного управління

Південноукраїнський національний педагогічний університет імені К.Д. Ушинського

вул. Старопортофранківська, 26, м. Одеса, Україна, 65020

E-mail: chernenkoirina02@gmail.com

ORCID ID: 0000-0003-3023-5479

\title{
МАРКЕТИНГОВІ СТРАТЕГІЇ У КОНТЕКСТІ КОНКУРЕНТОСПРОМОЖНОСТІ ЗАКЛАДУ ВИЩОЇ ОСВІТИ
}

У статті розглядаються теоретичні засади маркетингових стратегій, представлено компоненти, що фрормують маркетингову стратегію закладу вищої освіти. У дослідженні використано методи аналізу та синтезу. Мета дослідження полягала у вивченні та аналізі діючих на цільових ринках конкурентних стратегій 3ВО з метою досягнення конкурентних переваг. Проаналізовано підходи до визначення ключових понять дослідження: стратегія, маркетингова стратегія, конкуренція, конкурентоспроможність. Визначено специфіку ЗВО як суб'єкта ринкових відносин. Розглянуто конкурентні стратегії, способи досягнення конкурентних переваг, представлено модифріковану систему конкурентних стратегій 3ВО. Доведено, що реалізація конкурентних стратегій ЗВО забезпечує стійку перевагу перед конкурентами та вирішує актуальні стратегічні проблем.

Ключові слова: заклад вищої освіти, маркетинг, конкурентоспроможність, конкурентні стратегії, конкурентні переваги.

This work is licensed under a Creative Commons Attribution 4.0 International License http://creativecommons.org/licenses/by/4.0/

Постановка проблеми та її зв'язок з важливими науковими та практичними завданнями. Реформування вітчизняної вищої освіти в цілому і системи управління її якістю зокрема, потребують модернізації процесу стратегічного планування конкурентоспроможності закладу вищої освіти, що в свою чергу потребує успішної маркетингової політики на національному ринку освітніх послуг. Маркетинг освітніх послуг передбачає вивчення, формування та задоволення освітніх потреб споживачів через розроблення та надання освітніх послуг на цільових ринках.

Заклади вищої освіти на ринку надають комплекс освітніх послуг спрямований на задоволення потреб споживачів 3 метою зміни їхнього освітнього рівня (фахової підготовки). Відповідно до статті 1. Закону Про освіту України, освітня послуга - комплекс визначених законодавством, освітньою програмою та/або договором дій суб'єкта освітньої діяльності, що мають визначену вартість та спрямовані на досягнення здобувачем освіти очікуваних результатів навчання [9].

Т. Оболенська зазначає, що специфічною характеристикою освітнього маркетингу є розробка та реалізація стратегії формування та прирощення цінності людини. У зв'язку з чим, мета маркетингу в освіті полягає у формуванні цінності людини та задоволення ії потреб у розвитку [15].

Звернемо у вагу на те, що задоволення потреб у розвитку $є$ важливим не лише для людини, як споживача освітніх послуг, а й для стейкхолдерів 3ВО: роботодавців, академічної спільноти, держави та суспільства. Це визначає ключову особливість ЗВО як суб'єкта ринкових відносин, яка полягає у тому, що разом з економічною, забезпечується і соціальна функцію - відтворення інтелектуального потенціалу суспільства.

Зазначимо, що ЗВО на відміну від інших суб'єктів ринкових відносин, здійснює діяльність і на ринку освітніх послуг і на ринку праці. Специфікою ЗВО як суб'єкта ринкових відносин $є$ і те, що грошові кошти за освітні послуги ЗВО отримує не від кінцевого споживача - підприємства, установи, а від проміжного споживача - здобувача освіти. Цим, певною мірою, пояснюється стихійне відкриття спеціальностей, адже попит породжує пропозицію, що у результаті призводить до перевиробництва одних кадрів і браку інших.

Відомо, що потреба у фахівцях на ринку праці не $\epsilon$ постійною величиною і залежить від кожної окремої професії та визначається певними етапами 
економічного розвитку країни. Щоб збалансувати попит і пропозицію на ринку потрібно знати скільки, яких спеціалістів і з якими компетентностями потрібно готувати 3ВО.

Погоджуємось 3 думкою Н. Гуржій, що ринкові економічні трансформації вимагають розгляду всіх сфер діяльності підприємства (ЗВО) з позиції маркетингу. Таким чином, вся система управління діяльністю підприємства повинна мати маркетингову орієнтацію [8].

У цьому контексті, кожен заклад вищої освіти може ефективно управляти маркетинговою діяльністю, за умови оперування інформацією щодо результатів сучасних досліджень ринкових можливостей та цільових ринків, результатів розробки ефективного маркетингового комплексу та ефективного управління маркетинговою діяльністю тощо.

I. Баша виділяє актуальні напрями маркетингових досліджень, зокрема: «... дослідження тенденцій у сфері вищої освіти та аналіз ринку освітніх послуг; аналіз попиту на послуги університету; дослідження конкуренції та конкурентний бенчмаркінг; визначення перспективних сфер для зростання; дослідження ринку праці й зайнятості; проведення інтерв'ю з роботодавцями; аналіз іміджу ЗВО у регіоні, країні, світі; дослідження у сфері брендингу університету; SWOT-аналіз; дослідження задоволеності студентів навчанням; оцінювання потреб студентів; дослідження успіху студентів; дослідження задоволеності співробітників; дослідження потреб співробітників; сприйняття закладу освіти випускниками та спонсорами; моніторинг розвитку професійної кар'єри випускників» [3; с.114].
В умовах зростання конкуренції виникає необхідність розробки та реалізації індивідуальних конкурентних стратегій 3ВО, з метою максимальної актуалізації конкурентних переваг на цільовому сегменті ринку, що і визначає актуальність дослідження.

Аналіз останніх публікацій 3 проблеми. Дослідженням конкурентоспроможності закладів освіти та впливу на неї маркетингових стратегій займалися відомі вітчизняні та зарубіжні науковці, зокрема: I. Баша, А. Бідюк, Б. Братаніч, І. Должанський, Н. Гуляєва, Т. Загорна, Г. Кривенко, С. Натрошвілі, Т. Оболенська, О. Пакулін, М. Савельєва, Р. Фатхутдінов, І. Чайка, Н. Шарай, В. Шереметова, I. Ансофф, Ф. Котлер, М. Портер, Т. Петерс та інші. Науковцями доведено, що цільова спрямованість маркетингових стратегій визначається метою управління як орієнтиром, що уточнюється у процесі розробки та реалізації обраної стратегії.

Формулювання цілей дослідження. Посилення конкуренції, політика державного замовлення на підготовку фахівців, зміна поведінки і вимог споживачів освітніх послуг та інші чинники зовнішнього середовища посилюють увагу керівництва до конкурентних стратегій ЗВО. Мета дослідження полягала у вивченні та аналізі діючих на цільових ринках конкурентних стратегій ЗВО з метою досягнення конкурентних переваг.

Виклад основних результатів та їх обгрунтування. Науковці у сфері економіки та менеджменту з різних позицій тлумачать сутність понять «стратегія», «маркетингова стратегія». Аналіз енциклопедичних, науково-методичних, економічних та інших джерел надав можливість узагальнити підходи щодо їх визначення (таблиці 1;2).

Таблиця 1

Сутність поняття «стратегія» у тлумаченні різних авторів*

\begin{tabular}{|c|l|r|}
\hline \multicolumn{1}{|c|}{ Автор } & \multicolumn{1}{|c|}{ Тлумачення поняття «стратегія» } & Джерело \\
\hline $\begin{array}{l}\text { М. Мескон, } \\
\text { М. Альберт, } \\
\text { Ф. Хедоури }\end{array}$ & $\begin{array}{l}\text { Детальний всебічний комплексний план, призначений для того, щоб забезпечити } \\
\text { здиння місії організації та їі досягнення. }\end{array}$ & {$[14]$} \\
\hline $\begin{array}{l}\text { I. Ансофф, } \\
\text { М. Портер }\end{array}$ & $\begin{array}{l}\text { Показує, в якій сфері господарської діяльності діє компанія, в якому напряму вона } \\
\text { має намір розвиватися, та прагне зайняти конкурентну позицію в галузі. }\end{array}$ & {$[2]$} \\
\hline Б. Карллоф & $\begin{array}{l}\text { Узагальнююча модель дій, необхідних для досягнення поставленої мети шляхом } \\
\text { координації та розподілу ресурсів компанії. }\end{array}$ & {$[10]$} \\
\hline $\begin{array}{l}\text { А. Гершун, } \\
\text { М. Горский }\end{array}$ & $\begin{array}{l}\text { Шлях компанії, що складається з декількох етапів і який вона повинна пройти від } \\
\text { свогоперішнього стану до того цільового стану, який планується і передбачаєть- }\end{array}$ & [7] \\
\hline
\end{tabular}

* Узагальнено авторами із використанням джерел $[2 ; 7 ; 10 ; 14]$

Наукові підходи щодо тлумачення сутності поняття «маркетингова стратегія» узагальнено та представлено у табл. 2.

У контексті вирішення завдань дослідження розглянемо тлумачення науковцями понять «конкуренція» та «конкурентоспроможність».

За Г. Азоєвим, А. Челенковим конкурентоспроможність - це спроможність ефективно розпоряджатися власними і позиковими ресурсами в умовах конкурентного ринку [1].

Р. Фатхутдінов зазначає, що конкурентоспро- можність - це властивість об'єкта, що характеризується рівнем реального або потенційного задоволення ним конкретної потреби порівняно 3 аналогічними об'єктами, що представлені на певному ринку. На думку дослідника конкурентоспроможність закладу вищої освіти - це підготовка фахівців, які зможуть вести конкуренту боротьбу на внутрішньому та зовнішньому ринку праці; спроможність розробляти конкурентні інновації та вміння вести ефективну політику в усіх сферах діяльності закладу вищої освіти [21]. 
Таблиця 2

Наукові підходи щодо сутності поняття «маркетингова стратегія»

\begin{tabular}{|l|l|c|}
\hline \multicolumn{1}{|c|}{ Автор } & \multicolumn{1}{|c|}{ Тлумачення поняття «маркетингова стратегія» } & Джерело \\
\hline Т. Лук’янець & $\begin{array}{l}\text { Маркетингова логіка, яка забезпечує досягнення ринкових цілей і складається } \\
\text { зі спеціальних стратегій щодо цільових сегментів, комплексу маркетингу, рівня } \\
\text { маркетингових витрат. }\end{array}$ & [13] \\
\hline Ф. Котлер & $\begin{array}{l}\text { Рішення в галузі маркетингу та інновацій, що визначають напрям, в якому ру- } \\
\text { хається компанія, виконуючи поставлені завдання. }\end{array}$ & [12] \\
\hline $\begin{array}{l}\text { Г. Хулей, } \\
\text { Дж. Сондерс, } \\
\text { Н. Пірс }\end{array}$ & $\begin{array}{l}\text { Забезпечення відповідності можливостей компанії умовам конкурентного рин- } \\
\text { ку, на яких вона працює, не тільки на сьогодні, але й у майбутньому }\end{array}$ & [23] \\
\hline Х. Хершген & $\begin{array}{l}\text { Принципові, середні і довгострокові рішення, що визначають орієнтири і спря- } \\
\text { мовують певні заходи маркетингу на досягнення поставлених цілей. }\end{array}$ & [22] \\
\hline
\end{tabular}

*Узагальнено авторами із використанням джерел $[12 ; 13 ; 22 ; 23]$

Конкурентна боротьба закладу вищої освіти на ринку освітніх послуг потребує розробки та реалізації маркетингових конкурентних стратегій.

Зазначимо, що стратегія маркетингового управління закладом вищої освіти - це функціональна стратегія, що забезпечує обгрунтованість цілей i завдань на кожному окремому ринку (сегменті ринку) і кожної освітньої послуги з урахуванням особливостей конкурентного середовища, конкуренції і попиту споживачів. Стратегія маркетингового управління $\epsilon$ системою дій закладу вищої освіти щодо вибору цільового ринку, забезпечення споживчої цінності освітніх послуг, та ефективного просування освітніх послуг на ринок.

Не викликає сумніву, що ефективність системи функціонування ЗВО, його конкурентоспроможність залежить від реалізації актуальної та затребуваної концепції холістичного (цілісного) маркетингу, що грунтується (за Ф. Котлерем, К. Келлерем) на плануванні, розроблені та впровадженні маркетингових програм, процесів і заходів з урахуванням їх широти та взаємозалежності. Структуровано холестичний маркетинг являє собою єдність компонентів маркетинг стосунків, інтегрований маркетинг, внутрішній маркетинг та соціально-етичний маркетинг [12]. Концепція холістичного маркетингу передбачає зосередження уваги на елементах інтегрованих бізнес-взаємодій підприємства 3 клієнтами, постачальниками і посередниками, 3 урахуванням інтересів зацікавлених сторін: клієнтів, співробітників, постачальників, акціонерів, суспільство і навколишнє середовище (за Н. Герасимяк) [6].

I. Чайкою запропоновано основні напрями діяльності 3ВО на засадах концепції холістичного маркетингу, зокрема:

- постійний моніторинг потреб споживачів, їхнього стилю життя, проблем, що заважають споживачам досягти бажаного стану, і пошук на його основі нових продуктів та способів обслуговування з урахуванням цінностей та інтересів цільової аудиторії;

- навчання кожного співробітника і підрозділу 3ВО, стимулювання їхньої зацікавленості у реалізації концепції холістичного маркетингу ЗВО, тобто кожен співробітник повинен розглядатися з точки зору ефективності обслуговування споживачів [24. С. 56].

Система конкурентних стратегій ЗВО побу- дована на засадах концепції холістичного маркетингу дає змогу визначити напрям та зміст діяльності в кожній стратегічній сфері освітніх послуг і спрямовувати діяльність закладу освіти на забезпечення стійких конкурентних позицій на ринку, забезпечення і підтримку довгострокових конкурентних переваг. При цьому потрібно орієнтуватися на максимальну та своєчасну адаптацію до динамічного маркетингового середовища 3 метою досягнення закладом освіти стратегічних конкурентних цілей на засадах певних конкурентних стратегій [24].

Зробити оптимальний вибір конкурентної стратегії є складним завданням, тому сучасному ЗВО як суб'єкту ринкових відносин необхідно послуговуватися класифікаціями конкурентних стратегій на засадах різних концептуальних підходів, зокрема: А. А. Томпсон і Дж. Стрикленд [19] класифікують конкурентні стратегії на наступальні та оборонні; М. Портер конкурентні стратегії класифікує за типом конкурентної переваги; Г. Азоєв - за поділом підприємств на лідерів ринкового сегменту, підприємства 3 сильною конкурентною позицією, підприємства зі слабкою конкурентною позицією та аутсайдери [1]; Ф. Котлер класифікує конкурентні стратегії за характером дій, рівнем агресивності підприємств на ринку: лідер ринку, претендент на лідерство, наслідувач, фахівець [12]; Х. Фрізевінкиль, Л. Раменський класифікують конкурентні стратегії на засадах факторного підходу: віолентна (силова), патієнтна (нішова), комутантна (пристосовницька), експлерентна (піонерська) стратегії [20]. Вочевидь, що класифікації є похідними та доповнюють одна одну, що надає можливість їх комбінувати.

На думку дослідників система конкурентних стратегій повинна базуватися на ринковому досвіді підприємства, його іміджі та фінансових ресурсах. Науковці (С. Клименко, О. Дуброва, Д. Барабась, Т. Омельяненко., А. Вакуленко та ін.) зазначають, що підприємство (ЗВО) повинно визначити перелік наявних активів (можливості у конкурентній боротьбі за ринок) та надати оцінку, а саме: переважають чи поступаються ці активи, або дорівнюють відповідним активам конкурентів [11].

Науковці виділяють компоненти маркетингових конкурентних стратегій, зокрема: швидкість зростання - фіксує, які маркетингові заходи забезпечува- 
тимуть майбутнє зростання закладу вищої освіти (зростання частки ринку, розширення ринку, диверсифікація освітніх послуг); диференціація ринку виявляє, що відрізняє заклад вищої освіти, на погляд споживачів, від конкурентів та відносну частку ринку, котру заклад вищої освіти прагне зайняти; диференціація продуктів - показує відмінність освітніх послуг конкретного закладу вищої освіти від інших конкурентів.

Зазначимо, що базою будь-якої конкурентної маркетингової стратегії мають бути конкурентні переваги, що являють собою унікальні конкурентні активи закладу вищої освіти.

На думку О. Тимошенко складовими стратегії забезпечення конкурентоспроможності закладу вищої освіти є [18]:

- стратегія удосконалення управління вищою освітою, а саме: розроблення методики і системи показників для оцінки діяльності закладів вищої освіти, забезпечення моніторингу їх діяльності; вдосконалення державного замовлення на підготовку фахівців;

- стратегія нарощування потенціалу науково-педагогічного складу закладу вищої освіти та підвищення його соціального статусу;

- стратегія оптимізації структури закладів вищої освіти у контексті приведення у відповідність їх кількості до високорозвинених і високоосвічених європейських країн;

- стратегія посилення міжнародного співробітництва закладів вищої освіти України у контексті інтеграції освітніх програм, освітніх технологій та наукових досліджень;

- стратегія удосконалення якості освітнього процесу шляхом упровадження сучасних освітніх технологій;

- стратегія підвищення конкурентоздатності випускників і розвиток системи працевлаштування; - стратегія покращення фінансовоекономічного механізму функціонування закладів вищої освіти, створення системи багатоканального фінансування вищої освіти;

- стратегія створення умов щодо зацікавленості працевлаштування молоді в Україні, що сприя-

тиме підвищенню позиції у рейтингу «здатність країни до втримання талантів»;

- стратегія створення умов щодо представлення вітчизняних закладів вищої освіти у міжнародних базах даних, посилення наукових розробок науково-педагогічного складу, публікація результатів у зарубіжних виданнях.

Водночас, необхідно враховувати критерії рейтингових оцінок при розробці та затвердженні Концепції наукової, навчальної та позанавчальної діяльності закладів вищої освіти в Україні [18].

Л. Вербівська, І. Судук визначають стратегію забезпечення конкурентоспроможності підприємства (3ВО) як комплексну стратегію, котра включає довгострокові програми дій за всіма функціональними напрямами діяльності, що спрямовані на формування належного рівня конкурентного потенціалу і конкурентоспроможності та характеризується як здатність підприємства завойовувати ринкові ніші, адаптуватись до умов конкурентного середовища, надавати послуги якісніші за конкурентів [5]. Отже, мова йде про конкурентні переваги.

Зазначимо, що конкурентна перевага забезпечує стійкі позиції закладу вищої освіти на ринку і прибуток на рівні вище середнього у галузі, завдяки високому рівню якості освітніх послуг і можливостей у певній сфері чи напряму діяльності (велика частка ринку; зростаючий контингент здобувачів освіти; лідируюча стратегія; вдале положення закладу вищої освіти на ринку; диференціація освітніх послуг закладу вищої освіти; концентрація на швидко зростаючих сегментах ринку; освітньо-технологічні та інноваційні переваги закладу вищої освіти; високий рівень менеджменту та маркетингу тощо) [3; 4; 15; 21; 24].

М. Портер виділяе три базові конкурентні стратегіі, що мають універсальний характер, тобто можуть бути використані в будь-якому конкурентному середовищі будь-яким закладом вищої освіти і забезпечити конкурентні переваги: лідерство за витратами (дає можливість знижувати вартість освітніх послуг); диференціація (освітні послуги на ринку); фокусування (концентрація зусиль у сегменті ринку) [16].

Характеристика конкурентних стратегій закладів вищої освіти представлено в табл. 3 .

Таблиця 3

Характеристика конкурентних стратегій закладів вищої освіти*

\begin{tabular}{|c|c|c|}
\hline $\begin{array}{c}\text { Стратегія найменших сукупних } \\
\text { витрат }\end{array}$ & Стратегія диференціації & Стратегія фокусування \\
\hline \multicolumn{3}{|l|}{ Сутність підходу } \\
\hline $\begin{array}{l}\text { Намагання надавати освітні пос- } \\
\text { луги за цінами нижчими ніж у } \\
\text { конкурентів. }\end{array}$ & $\begin{array}{l}\text { Намагання надати освітнім пос- } \\
\text { лугам рис, відмінних від послуг- } \\
\text { конкурентів. }\end{array}$ & $\begin{array}{l}\text { Концентрація зусиль у сегменті } \\
\text { ринку, а не робота на усьому рин- } \\
\text { ку. }\end{array}$ \\
\hline \multicolumn{3}{|c|}{ Стратегічна ціль } \\
\hline Завоювання великої частки ринку. & $\begin{array}{l}\text { Завоювання великої частки рин- } \\
\text { ку. }\end{array}$ & Завоювання певної ніші ринку. \\
\hline \multicolumn{3}{|c|}{ Основа конкурентної переваги } \\
\hline $\begin{array}{l}\text { Спроможність забезпечити зага- } \\
\text { льний рівень витрат нижчий, ніж у } \\
\text { конкурентів. }\end{array}$ & $\begin{array}{l}\text { Здатність запропонувати здобу- } \\
\text { вачам освітні послуги відмінні } \\
\text { від освітніх послуг конкурентів. }\end{array}$ & $\begin{array}{l}\text { Більш низькі витрати при задово- } \\
\text { лені запитів певної ніші ринку. }\end{array}$ \\
\hline
\end{tabular}


Продовження табл. 3

\begin{tabular}{|c|c|c|}
\hline $\begin{array}{c}\text { Стратегія найменших сукупних } \\
\text { витрат }\end{array}$ & Стратегія диференціації & Стратегія фокусування \\
\hline \multicolumn{3}{|c|}{ Умови формування } \\
\hline $\begin{array}{l}\text { 1. Велика частка на ринку і низька } \\
\text { ціна освітніх послуг. } \\
\text { 2. Цінова еластичність попиту на } \\
\text { освітні послуги. } \\
\text { 3. Цінова конкуренція. } \\
\text { 4. Відсутність ефективної дифере- } \\
\text { нціації. }\end{array}$ & $\begin{array}{l}\text { 1. Наявність широких можливос- } \\
\text { тей освітніх послуг на ринку. } \\
\text { 2. Різноманітна структура попиту } \\
\text { на освітні послуги. } \\
\text { 3. Нецінова конкуренція. } \\
\text { 4. Нерозвиненість стратегії ди- } \\
\text { ференціації освітніх послуг. }\end{array}$ & $\begin{array}{l}\text { 1. Урізноманітнення споживачів } \\
\text { за цільовим використанням освіт- } \\
\text { ніх послуг. } \\
\text { 2. Відсутність спеціалізації кон- } \\
\text { курентів на ринку. } \\
\text { 3.Обмеженість можливостей за- } \\
\text { кладу вищої освіти щодо обслуго- } \\
\text { вування всього ринку. }\end{array}$ \\
\hline \multicolumn{3}{|c|}{ Перелік освітніх послуг } \\
\hline Якісні профільні освітні послуги. & $\begin{array}{l}\text { Значний перелік освітніх послуг } \\
\text { та можливість широкого вибору. }\end{array}$ & $\begin{array}{l}\text { Перелік освітніх послуг для задо- } \\
\text { волення особливих запитів обра- } \\
\text { ного сегмента ринку. }\end{array}$ \\
\hline \multicolumn{3}{|c|}{ Головний принцип організації освітньої діяльності } \\
\hline $\begin{array}{l}\text { Пошук можливостей для зниження } \\
\text { витрат без втрати якості освітніх } \\
\text { послуг. }\end{array}$ & $\begin{array}{l}\text { Пошук нових способів кращого } \\
\text { задоволення запитів здобувачів } \\
\text { освіти. }\end{array}$ & $\begin{array}{l}\text { Індивідуалізація освітніх послуг } \\
\text { для задоволення особливих запи- } \\
\text { тів здобувачів освіти. }\end{array}$ \\
\hline
\end{tabular}

*Узагальнено авторами із використанням джерел $[3 ; 4 ; 15 ; 16 ; 21 ; 24]$

Для досягнення конкурентних переваг заклади вищої освіти використовують: забезпечення високоякісного освітнього процесу; бездоганна організація надання широкого переліку освітніх послуг здобувачам; наявність авторських освітніх програм, технологій; забезпечення розробки та впровадження інноваційних освітніх технологій випереджуючи конкурентів; бездоганна репутація; постійне спостереження за розвитком потреб здобувачів за цільовими групами; географічне розташування закладу вищої освіти тощо .

Досягнення конкурентних переваг забезпечують наступальні чи оборонні дії (залежно від ситуації на ринку освітніх послуг), застосування короткострокових тактичних (миттєве реагування на ситуацію) та довгострокових дій, що визначають майбутні конкурентні можливості закладу вищої освіти та його позицію на ринку освітніх послуг.

Дослідники С. Клименко, Т. Омельяненко, Д. Барабась, А. Вакуленко розглядають систему маркетингових конкурентних стратегій, як сукупність стратегій, що спрямовані на адаптацію підприємства (у контексті дослідження - заклад вищої освіти) до змін в умовах конкуренції та зміцнення його довгострокової конкурентної позиції на ринку [11]. Автори до цієї системи відносять: стратегію формування конкурентних переваг; стратегію забезпечення конкурентоспроможності підприємства; стратегію конкурентної поведінки. Модифіковану систему конкурентних стратегій закладу вищої освіти представлено на рис. 1.

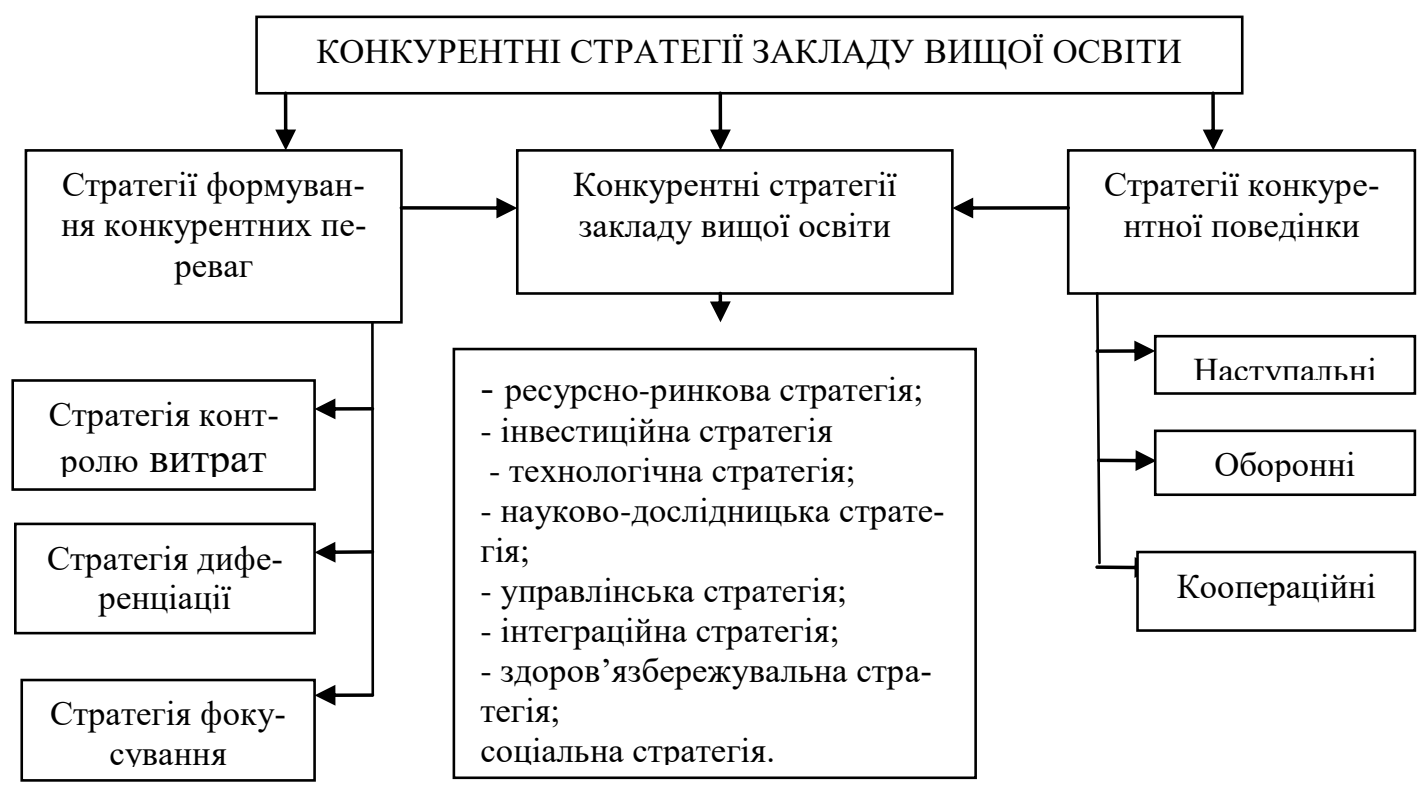

Рис. 1. Модифікована система конкурентних стратегій закладу вищої освіти* *розроблено авторами $з$ використанням джерел $[4 ; 11 ; 16 ; 21]$ 
Визначені види стратегій взаємозв'язані, найважливішою умовою успішного функціонування закладу вищої освіти на ринку освітніх послуг є обгрунтування і реалізація цих стратегій на кожному рівні управління.

Поділяємо думку Р. Фатхудінова стосовно того, що маркетингова стратегія закладу вищої освіти має специфічні характеристики, зокрема: бути довгостроково орієнтованою; бути засобом реалізації маркетингових цілей закладу освіти; базуватися на результатах стратегічного аналізу маркетингового середовища; мати певну підпорядкованість в ієрархії стратегій і бути складовою частиною стратегічної піраміди закладу вищої освіти; визначати ринкове спрямування діяльності закладу вищої освіти стосовно споживачів або / та стосовно конкурентів на ринку освітніх послуг; виявляти сильні сторони закладу вищої освіти, що дозволятимуть йому отримати перемогу в конкурентній боротьбі, а саме визначати його конкурентну перевагу [21].

I. Баша для ведення ефективної конкурентної боротьби пропонує відповідні заходи, зокрема: аналіз переваг та недоліків конкурентів, власних переваг i недоліків $з$ метою розроблення програми дій щодо їх

подолання; аналіз чинників, що впливають на поведінку потенційних абітурієнтів під час вибору закладу вищої освіти та спеціальності; розробка комплексу дій з популяризації закладу вищого освіти 3 метою створення та підтримки позитивної репутації в суспільстві; ефективна політики ціноутворення [3; с.48]

Висновки та перспективи подальших досліджень. Таким чином, характерні риси конкурентних стратегій визначають засоби конкурентної боротьби закладу вищої освіти на цільових ринках. Конкурентні стратегії є своєчасною реакцією на зміни в галузі освіти, в економіці та політиці держави. Конкурентні стратегії спроможні забезпечити стійку перевагу перед конкурентами та вирішувати актуальні стратегічні проблеми.

Перспективу подальших досліджень вбачаємо у вивченні внутрішнього середовища ЗВО з метою визначення рівня його конкурентоспроможності та розробці комплексу заходів щодо формування конкурентних переваг, з метою забезпечення успішної діяльності 3ВО в умовах постійно мінливих запитів споживачів освітніх послуг і конкурентного оточення.

\section{Література}

1. Азоев Г. Л. Челенков А. П. Конкурентные преимущества фирмы. М.: Новости, 2006. 267 с.

2. Ансофф И. Стратегическое управление. URL: http://www.vuzlib.net/beta3/html/1/5182/ (дата звернення: 20.05.2020).

3. Баша I. М. Маркетингові дослідження на ринку освітніх послуг: дис. ...канд..екон.наук : 08.00.04: захист: 02.02.2015 р. / наук. кер. А.Ф. Павленко. Київ: Київ. нац.. екон. ун-т ім. Вадима Гетьмана, 2015 р. 178 с.

4. Бідюк А. Л. Формування конкурентної стратегії закладу вищої освіти : автореф. дис. на здобуття наук. ступеня канд. екон. наук: 08.00.04: захист: 02.07. 2020 р./ наук. кер. А. М. Гуляєва. Київ: Київ. нац. Торг.екон. ун-т, 2020. 23 с.

5. Вербівська Л. В., Судук І. В. Стратегія забезпечення конкурентоспроможності підприємства та основні принципи іï формування // Молодий вчений. 2017. № 10 (50) URL: ..//http://molodyvcheny.in.ua/files/journal/2017/10/188.pdf (дата звернення: 18.07.2020).

6. Герасимяк Н. В. Холістичний маркетинг як нова парадигма розвитку маркетингу // Ефективна економіка. 2012. № 7. URL: http://nbuv.gov.ua/UJRN/efek_2012_7_35 (дата звернення: 20.06.2020).

7. Гершун А. Горский М. Технологии сбалансированного управления. М.: ЗАО“Олимп-бизнес”, 2005. $416 \mathrm{c}$.

8. Гуржій Н. М. Управління маркетингом: концепції та проблеми // Вісник Національного університету «Львівська політехніка». 2011. № 720: Менеджмент та підприємництво в Україні: етапи становлення і проблеми розвитку. C. 16-22. URL: http://ena.lp.edu.ua/bitstream/ntb/13812/1/4_16-22_Vis_720_Menegment.pdf

9. Про освіту: Закон України за станом 24.06.2020 p. / Верховна Рада України. URL: https://zakon.rada.gov.ua/laws/show/2145-19\#Техt (дата звернення: 18.07.2020).

10. Карллоф Б. Деловая стратегия / пер с англ. О.Д. Горин. М.: Экономика, 1991. 239 с.

11. Управління конкурентоспроможністю підприємства / Клименко С. М. та ін.

2006. 524 c. URL:http://www.twirpx.com/file/71310.htm (дата звернення: 02.07.2020).

12. Котлер Ф., Келлер К. Маркетинг менеджмент. Экспресс-курс. СПб.: Питер, 2010. 480 с

13. Лук'янець Т. І. Рекламний менеджмент: навч.-метод. посіб. К.: КНЕУ. 2002. 200 с.

14. Мескон М. Х., Альберт М., Хедоури Ф. Основы менеджмента / пер. с англ. под. ред. Л. И. Евенко. М.: Дело, 2005. 720 с.

15. Оболенська Т. С. Маркетинг у сфері освітніх послуг: автореф. дис. ... д-ра економ. наук: 08.06.02: захист: 23 05. 2002 р. Х. : Харк. держ. екон. ун-т, 2002. 33 с.

16. Портер М. Конкурентна перевага. Як досягати стабільно високих результатів / пер. с англ. І.Гнатовська, І.Ємельянова. К.: Наш Формат, 2019. 624 с.

17. Про національну стратегію розвитку освіти в Україні на період до 2021 року: Указ Президента України від 25.06.2013 № 344 // Урядовий кур’єр. 2013. 4 лип. 
18. Тимошенко О. В. Економічний освітній простір України: сучасні тенденції та перспективи розвитку // Формування ринкових відносин в Україні. 2014. № 5 (156). С. 194-199.

19. Томпсон А. А. Стратегический менеджмент. Искусство разработки и реализации стратеги / пер. с англ. под ред. Л. Г.Зайцева, М.И. Соколовой. М.: Банки и биржи, ЮНИТИ. 1998. 576 с.

20. Фатхутдинов Р. А. Конкурентоспособность: экономика, стратегия, управление. М.: Инфра-М, 2000. $312 \mathrm{c}$.

21. Фатхутдинов Р. А. Управление конкурентоспособностью Вуза // Высшее образование в России. 2006. № 9. С. 37-38.

22. Хершген Х. Маркетинг: основы профессионального успеха / пер. с нем. А.М. Макаров. М. : ИНФРА-М, 2007. $315 \mathrm{c}$.

23. Хулей Г., Сондерс Дж., Пирси Н. Маркетинговая стратегия и конкурентное позиционирование / пер. с англ. Днепропетровск: Balance Business Books, 2013. 800 c.

24. Чайка І. П. Холістичний маркетинг і його значення у функціонуванні вищого навчального закладу // Маркетинг і менеджмент інновацій. 2013. №3. C. 53-60. URL: http://mmi.fem.sumdu.edu.ua/ (дата звернення: 20.07.2020).

Стаття надійшла 27.07.2020

Стаття прийнята до друку 11.08.2020

Доступно в мережі Internet 15.10.2020

Постоян Т.Г.

кандидат педагогических наук, доцент

кафедра образовательного менеджмента и публичного управления

E-mail: postoyantatyana@gmail.com

ORCID ID: 0000-0002-5549-8243

Черненко И.В.

магистрант

кафедра образовательного менеджмента и публичного управления

Южноукраинский национальный педагогический университет им. К.Д. Ушинского

ул. Старопортофранковская, 26, г. Одесса, Украина, 65020

E-mail: chernenkoirina02@gmail.com

ORCID ID: 0000-0003-3023-5479

\section{МАРКЕТИНГОВЫЕ СТРАТЕГИИ В КОНТЕКСТЕ КОНКУРЕНТОСПОСОБНОСТИ ВЫСШЕГО УЧЕБНОГО ЗАВЕДЕНИЯ}

Усиление конкуренции, политика государственного заказа на подготовку специалистов, изменение поведения и требований потребителей образовательных услуг и другие факторы внешней среды усиливают внимание топ-менеджеров к конкурентным стратегиям ВУЗа. В статье рассматриваются теоретические основы маркетинговых стратегий, представлены компоненты, формирующие маркетинговую стратегию ВУЗа. В исследовании использовались методы анализа и синтеза. Цель исследования состояла в изучении и анализе конкурентных стратегий ВУЗов на целевых рынках для достижения конкурентных преимуществ. Проанализированы подходы к определению ключевых понятий исследования: стратегия, маркетинговая стратегия, конкуренция, конкурентоспособность. Акцентировано внимание на то, что система конкурентных стратегий ВУЗа должна строиться на концепции холистического маркетинга, что дает возможность определить направление и содержание деятельности в каждой стратегической сфере образовательных услуг и направить деятельность ВУЗа на обеспечение устойчивых конкурентных позиций на рынке, обеспечение и поддержку длительных конкурентных целей.

Охарактеризована специфика образовательного маркетинга, заключающаяся в разработке и реализации стратегии формирования и наращивании ценности личности, удовлетворении ее потребности в развитии. Обоснована зависимость эффективности системы функционирования ВУЗа, его конкурентоспособности от реализации актуальной и востребованной концепции холистического маркетинга. Рассмотрены составляющие конкурентных стратегий ВУЗа, конкурентные преимущества, способы достижения конкурентных преимуществ; представлено модифицированную систему конкурентных стратегий высшего учебного заведения.

Конкурентные стратегии способны обеспечить устойчивое преимущество относительно конкурентов и решение актуальных стратегических проблем. Перспектива дальнейших исследований за- 
ключается в изучении внутренней среды ВУЗа с целью определения уровня его конкурентоспособности и разработки комплекса мероприятий, обеспечивающих формирование его конкурентных преимуществ.

Ключевые слова: высшие учебные заведения (ВУЗ), холистический маркетинг, конкурентоспособность, конкурентные стратегии, конкурентные преимущества.

\author{
Postoian T \\ Ph.D., Associate Professor \\ Department of Education Management and Public Administration \\ E-mail: postoyantatyana@gmail.com \\ ORCID ID: 0000-0002-5549-8243 \\ Chernenko I. \\ Undergraduate \\ Department of Education Management and Public Administration \\ South Ukrainian National Pedagogical University named K.D. Ushynsky \\ Staroportofrankivska str., 26, Odesa, Ukraine, 65020 \\ E-mail: chernenkoirina02@gmail.com \\ ORCID ID: 0000-0003-3023-5479
}

\title{
MARKETING STRATEGIES IN THE CONTEXT OF COMPETITIVENESS OF A HIGHER EDUCATIONAL INSTITUTION
}

Strengthening of competition, the policy of state order for training specialists, changing the behavior and requirements of consumers of educational services and other environmental factors increase the attention of top managers to the competitive strategies of the higher educational institution. The article discusses the theoretical foundations of marketing strategies, presents the components that form the marketing strategy of the higher educational institution. The study used methods of analysis and synthesis. The purpose of the research was to study and analyze the competitive strategies of higher educational institution in target markets to achieve competitive advantages. The approaches to defining the key concepts of the research have been analyzed: strategy, marketing strategy, competition, competitiveness. Attention have been focused on the fact that the system of competitive strategies of the higher educational institution should be based on the concept of holistic marketing, which makes it possible to determine the direction and content of activities in each strategic area of educational services and direct the activities of the university to ensure sustainable competitive positions in the market, ensure and support long-term competitive goals.

The specificity of educational marketing has been characterized, which consists in the development and implementation of a strategy for the formation and growth of the value of an individual, in meeting his/her need for development. The dependence of the efficiency of the system of functioning of the higher educational institution, its competitiveness on the implementation of the actual and demanded concept of holistic marketing has been substantiated. The components of the competitive strategies of the higher educational institution, competitive advantages, ways to achieve competitive advantages have been considered; a modified system of competitive strategies of a higher educational institution has been presented.

Competitive strategies can provide a sustainable advantage over competitors and solve pressing strategic problems. The prospect of further research is to study the internal environment of the higher educational institution in order to determine the level of its competitiveness and develop a set of measures to ensure the formation of its competitive advantages.

Key words: higher educational institutions (HEI), holistic marketing, competitiveness, competitive strategies, competitive advantages.

\section{References}

1. Azoev, G. L., \& Chelenkov, A. P (2006). Konkurentnyie preimuschestva firmyi. Moscow: Novosti.

2. Ansoff, I. Strategicheskoe upravlenie. Retrieved May 20, 2020, from http://www.vuzlib.net/beta3/html/1/5182/

3. Basha, I. M. (2015). Marketynhovi doslidzhennia na rynku osvitnikh posluh. [dissertation of kand. ekon. nauk: 08.00.04]. Kyiv: Kyiv. nats. ekon. un-t im. Vadyma Hetmana.

4. Bidiuk, A. L. (2020). Formuvannia konkurentnoi stratehii zakladu vyshchoi osvity. [avtoref. of dissertation of kand. ekon. nauk: 08.00.04]. Kyiv: Kyiv. nats. Torh.-ekon. un-t. 
5. Verbivska, L. V., \& Suduk, I. V. (2017). Stratehiia zabezpechennia konkurentospromozhnosti pidpryiemstva ta osnovni pryntsypy yii formuvannia. Molodyi vchenyi, (10 (50)). Retrieved July 18, 2020, from http://molodyvcheny.in.ua/files/journal/2017/10/188.pdf

6. Herasymiak, N. V. (2012). Kholistychnyi marketynh yak nova paradyhma rozvytku marketynhu. Efektyvna ekonomika, (7), Retrieved June 20, 2020, from http://nbuv.gov.ua/UJRN/efek_2012_7_35 biznes".

7. Gershun, A., \& Gorskiy, M. (2005). Tehnologii sbalansirovannogo upravleniya. Moscow: ZAO “Olimp-

8. Hurzhii, N. M. (2011). Upravlinnia marketynhom: kontseptsii ta problem. Visnyk Natsionalnoho universytetu «Lvivska politekhnika», (720),16-22. Retrieved July 18, 2020, from http://ena.lp.edu.ua/bitstream/ntb/13812/1/4_1622_Vis_720_Menegment.pdf

9. Pro osvitu: Zakon Ukrainy za stanom 24.06.2020 r. Retrieved July 18, 2020, from https://zakon.rada.gov.ua/laws/show/2145-19\#Text

10. Karllof, B. (1991). Delovaya strategiya (O. D. Gorin, Trans.). Moscow.: Ekonomika.

11. Klymenko, S. M. (2006). Upravlinnia konkurentospromozhnistiu pidpryiemstva. Retrieved July 2, 2020, from http://www.twirpx.com/file/71310.htm

12. Kotler, F., \& Keller, K. (2010). Marketing menedzhment. Ekspress-kurs. SPb.: Piter.

13. Luk'ianets, T. I. (2002). Reklamnyi menedzhment. Kyiv: KNEU.

14. Meskon, M. H., Albert, M., \& Hedouri, F. (2005). Osnovyi menedzhmenta (L. I. Evenko, Trans.). Moscow:

Delo.

15. Obolenska, T. Ye. (2002). Marketynh u sferi osvitnikh posluh. [avtoref. of doctoral dissertation: 08.06.02]. Kharkiv: Khark. derzh. ekon. un-t.

16. Porter, M. (2019). Konkurentna perevaha. Yak dosiahaty stabilno vysokykh rezultativ (I. Hnatovska, I. Yemelianova, Trans.). Kyiv: Nash Format.

17. Pro natsionalnu stratehiiu rozvytku osvity v Ukraini na period do 2021 roku: Ukaz Prezydenta Ukrainy vid 25.06.2013 № 344. (2013). Uriadovyi kur’ier.

18. Tymoshenko, O. V. (2014). Ekonomichnyi osvitnii prostir Ukrainy: suchasni tendentsii ta perspektyvy rozvytku. Formuvannia rynkovykh vidnosyn v Ukraini, (5 (156)), 194-199.

19. Tompson, A. A. (1998). Strategicheskiy menedzhment. Iskusstvo razrabotki i realizatsii strategi (L. G. Zaytseva, M. I. Sokolovoy, Trans.). Moscow: Banki i birzhi, YuNITI.

20. Fathutdinov, R. A. (2000). Konkurentosposobnost: ekonomika, strategiya, upravlenie. Moscow: Infra-M.

21. Fathutdinov, R. A. (2006). Upravlenie konkurentosposobnostyu Vuza. Vyisshee obrazovanie v Rossii, (9), $37-38$. INFRA-M.

22. Hershgen, H. (2007). Marketing: osnovyi professionalnogo uspeha (A. M. Makarov, Trans.). Moscow:

23. Huley, G., Sonders, Dzh., \& Pirsi, N. (2013). Marketingovaya strategiya i konkurentnoe pozitsionirovanie. Dnepropetrovsk: Balance Business Books.

24. Chaika, I. P. (2013). Kholistychnyi marketynh i yoho znachennia u funktsionuvanni vyshchoho navchalnoho zakladu. Marketynh $i$ menedzhment innovatsii, (3), 53-60. Retrieved July 20, 2020, from http://mmi.fem.sumdu.edu.ua/

Received 27 July2020

Approved 11 August 2020

Available in Internet 15.10.2020

Цитування згідно ДСТУ 8302:2015

Постоян Т.Г.,Черненко І.В. Маркетингові стратегії у контексті конкурентоспроможності закладу вищої освіти // Економіка харчової промисловості. 2020. Т.12, вип. 3. С. 51-59. doi: 10.15673/fie.v12i3.1816

Cite as APA style citation

Postoian, T., \& Chernenko, I. (2020). Marketing strategies in the context of competitiveness of a higher educational institution. Food Industry Economics, 12(3), 51-59. doi: 10.15673/fie.v12i3.1816 